ISSN 1392-3196 / e-ISSN 2335-8947

Zemdirbyste-Agriculture, vol. 105, No. 1 (2018), p. 11-20

DOI 10.13080/z-a.2018.105.002

\title{
The content of elements and quality parameters of winter rye grain as influenced by biochar-amended soil
}

\author{
Piotr KRASKA ${ }^{1}$, Sylwia ANDRUSZCZAK ${ }^{1}$, Patryk OLESZCZUK ${ }^{2}$, Michał ŚWIECA ${ }^{1}$, \\ Ewa KWIECIŃSKA-POPPE ${ }^{1}$, Paweł GIERASIMIUK ${ }^{1}$, Krzysztof RÓŻYŁO ${ }^{1}$, Edward PAŁYS ${ }^{1}$ \\ ${ }^{1}$ University of Life Sciences \\ Akademicka 13, 20-950 Lublin, Poland \\ E-mail: sylwia.andruszczak@up.lublin.pl \\ ${ }^{2}$ Maria Curie-Skłodowska University \\ Maria Skłodowska-Curie 5, 20-031 Lublin, Poland
}

\begin{abstract}
A field experiment was conducted on a Haplic Podzol (PZha) during the period 2012-2014. The aim of this study was to evaluate the grain chemical composition of winter rye grown on a biochar-amended soil. The following grain quality traits were determined: content of $\mathrm{N}, \mathrm{P}, \mathrm{K}, \mathrm{Mg}, \mathrm{Ca}, \mathrm{Cu}, \mathrm{Zn}, \mathrm{Mn}, \mathrm{Fe}$ and $\mathrm{B}$, total protein content (TPC), total starch content (TSC), reducing sugar content (RSC), phenolic content (PhC), flavonoid content (FC), chelating power $(\mathrm{ChP})$ and reducing power $(\mathrm{RP})$. Biochar was applied once before sowing winter rye in 2011 at three rates: $10 \mathrm{Mg} \mathrm{ha}^{-1}\left(\mathrm{BC}_{10}\right), 20 \mathrm{Mg} \mathrm{ha}^{-1}\left(\mathrm{BC}_{20}\right)$ and $30 \mathrm{Mg} \mathrm{ha}^{-1}\left(\mathrm{BC}_{30}\right)$. The biochar was pyrolyzed from wheat straw at $350-650^{\circ} \mathrm{C}$. Rye grain was evaluated each year after harvest, i.e. 12,24 and 36 months after biochar application to the soil.

At all assessment times, the $\mathrm{N}$ content in rye grain from the biochar-amended treatments was higher than in the control treatment $\left(\mathrm{BC}_{0}\right)$. In the first year of the study, the lowest $\mathrm{P}$ content $\left(3.40 \mathrm{~g} \mathrm{~kg}^{-1}\right)$ was determined in grain from the treatment $\mathrm{BC}_{30}$, while in the third year in the treatment $\mathrm{BC}_{10}\left(3.31 \mathrm{~g} \mathrm{~kg}^{-1}\right)$. At the second and third assessment times, the content of $\mathrm{K}, \mathrm{Mg}$ and $\mathrm{Zn}$ in grain from the biochar-amended treatments decreased with increasing biochar rate, whereas the $\mathrm{Mn}$ content increased. In the treatment $\mathrm{BC}_{30}$, at the first assessment time the grain $\mathrm{Ca}$ content was found to be lowest $\left(0.147 \mathrm{~g} \mathrm{~kg}^{-1}\right)$, while after 36 months it was highest $\left(0.302 \mathrm{~g} \mathrm{~kg}^{-1}\right)$. In the first and third years of the study, the $\mathrm{Cu}$ content in the treatment $\mathrm{BC}_{30}$ was higher than in the $\mathrm{BC}_{10}$ (by $31.6 \%$ and $57.3 \%$, respectively). At the second and third assessment times 24 and 36 months after biochar application, the $\mathrm{Fe}$ and $\mathrm{B}$ content in grain obtained from the treatments $\mathrm{BC}_{10}$ and $\mathrm{BC}_{20}$ was higher than in that harvested from the $\mathrm{BC}_{30}$ plots. In grain harvested from the plots where $20 \mathrm{Mg} \mathrm{ha}^{-1}$ biochar had been applied, the total protein content and total starch content were found to be higher than in grain from the plots where $30 \mathrm{Mg} \mathrm{ha}^{-1}$ had been applied (by $10.7 \%$ and $17.1 \%$, respectively). The highest reducing sugar content $\left(9.02 \mathrm{mg} \mathrm{g}^{-1}\right.$ dry weight (DW)) and phenolic content $\left(6.8 \mathrm{mg}\right.$ of gallic acid equivalent $\left.(\mathrm{GAE}) \mathrm{g}^{-1} \mathrm{DW}\right)$ were determined in rye grain from the $\mathrm{BC}_{10}$ plots. Soil amendment at different biochar rates did not have an unambiguous effect on the antioxidant capacity parameters (chelating power and reducing power) of rye grains.
\end{abstract}

Key words: biochar, elemental composition, grain quality, Secale cereale.

\section{Introduction}

Biochar is a product of thermal decomposition of organic matter during the pyrolysis process with limited oxygen access in the temperature range of $300-1000^{\circ} \mathrm{C}$ (Gul et al., 2015). Today, biochar is actively researched all over the world, because it can be a viable option for sustainable agriculture due to its potential as a long-term sink for carbon in soil and on account of its benefits for crops (Alburquerque et al., 2013). Studies to date have confirmed the beneficial influence of biochar amendment

on soil physical, chemical and biological properties (Oleszczuk et al., 2014; Olmo et al., 2014; PrendergastMiller et al., 2014; Cao et al., 2017; Pranagal et al., 2017). Biochar application results in an increase in $\mathrm{pH}$ in acidic soils and an increase in organic carbon content. As a result of that, an improvement in soil fertility and an increase in nutrient bioavailability occur (Lehmann et al., 2011; Alburquerque et al., 2013; Gul et al., 2015; Schimmelpfennig et al., 2015; Kraska et al., 2016).

Please use the following format when citing the article:

Kraska P., Andruszczak S., Oleszczuk P., Świeca M., Kwiecińska-Poppe E., Gierasimiuk P., Różyło K., Pałys E. 2018. The content of elements and quality parameters of winter rye grain as influenced by biochar-amended soil. Zemdirbyste-Agriculture, 105 (1): 11-20 DOI 10.13080/z-a.2018.105.002 
The use of biochar can reduce the consumption of mineral fertilizers (Zhang et al., 2012; Salim, 2016). It contains several nutrients necessary for plants, whose presence may contribute to increased crop yields (Farrell et al., 2014; Cao et al., 2017). In the opinion of Prendergast-Miller et al. (2014), biochar added to soil increases the availability of nutrients to plants - directly as a source of nutrients and indirectly by changing the soil nutrient content. In turn, Schulz et al. (2013) showed that biochar application did not have a direct impact on plant growth and soil fertility. However, many authors stress that the effect of biochar amendment on crop yields depends on many factors, such as the conditions of a given study or biochar type (Alburquerque et al., 2013; Kraska et al., 2016; Salim, 2016). The chemical composition of biochar is very variable and depends on the type of substrate and pyrolysis conditions. Biochar may contain harmful compounds such as heavy metals or polycyclic aromatic hydrocarbons (Kuśmierz et al., 2016).

In the available literature, there is little information on the effect of biochar on grain chemical composition and quality of crop plants. Some papers indicate that biochar application increases the content of macro- and microelements in cereal grain (Atkinson et al., 2010; Major et al., 2010; Salim, 2016). Due to the fact that most papers describe positive effect of biochar amendment on the concentration of available nutrients in the soil, we hypothesize that it can be a source of nutrients for plants during growth. The proposed experiment assumed that biochar application would result in an increase in the grain content of elements and contribute to an improvement in the quality of winter rye sown in a monoculture. The aim of this paper was to evaluate the chemical composition of winter rye grown on a biocharamended soil. The study focused on the effect of biochar rates $\left(10,20\right.$ and $\left.30 \mathrm{Mg} \mathrm{ha}^{-1}\right)$ on macro- and microelement content in grain as well as some quality parameters like total protein, total starch, reducing sugar, phenolic, flavonoid, chelating power and reducing power.

\section{Materials and methods}

Biochar characteristics. Biochar applied to soil was obtained from a commercial manufacturer and was produced by pyrolysis where the feedstock is thermochemically decomposed at a temperature range from $350^{\circ} \mathrm{C}$ (start of combustion) to $650^{\circ} \mathrm{C}$ (max. combustion temperature) in an oxygen-poor atmosphere $\left(1-2 \% \mathrm{O}_{2}\right)$. Biochar was produced from wheat straw and was provided by Mostostal Sp. z o.o., Wrocław, Poland. Physico-chemical characteristics of biochar used in the experiment were as follows: $\mathrm{pH}_{\mathrm{KCl}}$ 9.9; available forms of $\mathrm{P}-235.6 \mathrm{mg} \mathrm{kg}^{-1}, \mathrm{~K}-2344.6 \mathrm{mg} \mathrm{kg}^{-1}$ $\mathrm{Mg}-1163.2 \mathrm{mg} \mathrm{kg}^{-1} ; \mathrm{C}-53.87 \%, \mathrm{~N}-0.91 \%, \mathrm{H}-1.76 \%$, ratio of hydrogen to carbon -0.033 , ash content $-41.2 \%$; specific surface area $-26.3 \mathrm{~m}^{2} \mathrm{~g}^{-1}$ (Oleszczuk et al., 2014).

Weather conditions. In the 2011-2012 season, the total rainfall was only $70 \%$ of the long-term average (Fig.). The highest rainfall deficit occurred in the period from September to November and also from May to August. During these months, the total rainfall was lower than the long-term average for the relevant period by $77 \%$ and $27 \%$, respectively. The 2012-2013 season was much wetter, since during this season the total rainfall was higher than the long-term average by $22 \%$. The months of May and June were most abundant in rainfall and the total rainfall in these months, compared to the long-term average was almost twice higher. The 2013-2014 season in which a particularly high amount of rainfall was recorded was also quite wet, especially in May.

The average air temperature during the field experiment was above the long-term average for most of the months. This was particularly the case in the periods from March to September 2012, from May to August 2013 as well as from February to May and in July 2014 (Fig.).
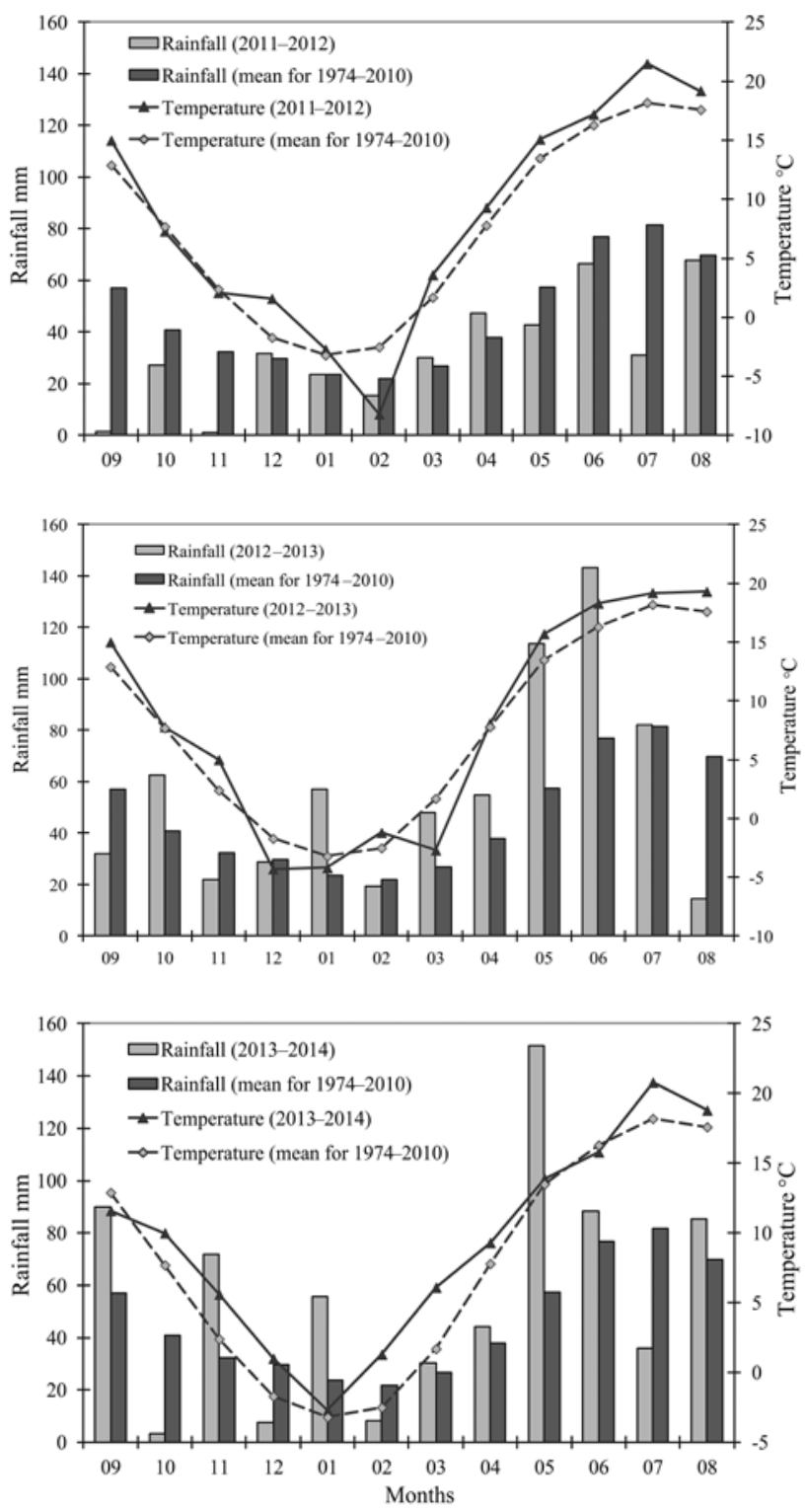

Figure. Rainfall and air temperature according to the Meteorological Station at Bezek, Poland in 2011-2014

Experimental site. The field study was conducted in the years 2012-2014 at the Experimental Farm in Bezek $\left(51^{\circ} 19^{\prime} \mathrm{N}, 23^{\circ} 25^{\prime} \mathrm{E}\right)$, Poland. The experiment was established on a Haplic Podzol (PZha) originating from glaciofluvial fine-grained loamy sand (WRB, 2014). The particle size distribution of arable layer of this soil was as follows: $2.0-0.5 \mathrm{~mm}$ fraction $-9 \%, 0.5-0.25 \mathrm{~mm}$ fraction 
$-24 \%, 0.25-0.05 \mathrm{~mm}$ fraction $-39 \%, 0.05-0.002 \mathrm{~mm}$ fraction $-26 \%$ and $<0.002 \mathrm{~mm}$ fraction $-2 \%$. In a three year study period the average amount of $\mathrm{P}$ in the soil was $59.42 \mathrm{mg} \mathrm{kg}^{-1}, \mathrm{~K}-108.53 \mathrm{mg} \mathrm{kg}^{-1}, \mathrm{Mg}-12.79 \mathrm{mg} \mathrm{kg}^{-1}$, $\mathrm{Cu}-1.83 \mathrm{mg} \mathrm{kg}^{-1}, \mathrm{Zn}-5.39 \mathrm{mg} \mathrm{kg}^{-1}, \mathrm{Mn}-116.07 \mathrm{mg} \mathrm{kg}^{-1}$, $\mathrm{Fe}-481.28 \mathrm{mg} \mathrm{kg}^{-1}, \mathrm{~B}-0.82 \mathrm{mg} \mathrm{kg}^{-1}$, and $\mathrm{pH}$ in $\mathrm{KCl}$ was 5.32 (Kraska et al., 2016). The experiment, set up in a randomized block design in three replicates, compared the effect of three biochar rates in the cultivation of winter rye (Secale cereale L., 'Dańkowskie Diament') cultivated in a monoculture. The area of a single plot was $18 \mathrm{~m}^{2}$. At the beginning of September 2011 biochar at rates of $10 \mathrm{Mg}\left(\mathrm{BC}_{10}\right), 20 \mathrm{Mg}\left(\mathrm{BC}_{20}\right)$ and $30 \mathrm{Mg}\left(\mathrm{BC}_{30}\right)$ per hectare was incorporated into the soil. Then the soil was ploughed and winter rye was sown in the fourth week of September 2011. The spacing between plots fertilized with the different rates of biochar was $2 \mathrm{~m}$. Plots in which no biochar was applied were the control treatment $\left(\mathrm{BC}_{0}\right)$.

The crop was sown at a rate of 5 million seeds per hectare at $12 \mathrm{~cm}$ inter-row spacing. Mineral fertilizers were applied every year of the experiment at the following rates: $70 \mathrm{~kg} \mathrm{ha}^{-1} \mathrm{~N}$ (ammonium nitrate), $26 \mathrm{~kg} \mathrm{ha}^{-1} \mathrm{P}$ (triple superphosphate), $66 \mathrm{~kg} \mathrm{ha}^{-1} \mathrm{~K}$ (muriate of potash, $\mathrm{KCl}$ ). Phosphorus and potassium fertilizers as well as $20 \mathrm{~kg} \mathrm{ha}^{-1} \mathrm{~N}$ were applied before sowing. In spring, the remaining portion of the nitrogen $(\mathrm{N})$ rate was applied before plant growth began $\left(30 \mathrm{~kg} \mathrm{ha}^{-1}\right)$ and at the stem elongation stage $\left(20 \mathrm{~kg} \mathrm{ha}^{-1}\right)$.

The winter rye crop protection program included the application of the herbicide Aminopielik Tercet 500 SL (a.i. 2.4 D $300 \mathrm{~g} \mathrm{l}^{-1}$, mecoprop $160 \mathrm{~g} \mathrm{l}^{-1}$ and dicamba $\left.40 \mathrm{~g} \mathrm{l}^{-1}\right)$ at a rate of $21 \mathrm{ha}^{-1}(\mathrm{BBCH} 23-29)$. Moreover, the fungicide Tango Star $334 \mathrm{SE}$ (a.i. fenpropimorph $250 \mathrm{~g} \mathrm{l}^{-1}$ and epoxiconazole $84 \mathrm{~g} \mathrm{l}^{-1}$ ) was applied at a rate of $11 \mathrm{ha}^{-1}$ (BBCH 51-56).

Grain analyses. The winter rye grain was sampled every year after harvest $(12,24$ and 36 months after biochar application). In composite samples from each treatment, the content of the following elements was determined in three replicates: $\mathrm{N}$ - mineralization in sulfuric acid and oxygenated water, determination by the Kjeldahl distillation method, titration detection; $\mathrm{P}$ - mineralization in sulfuric acid and oxygenated water, determination by the vanadium-molybdate spectrophotometric method, spectrophotometer Spekol (Carl Zeiss AG, Germany); $\mathrm{K}$ and $\mathrm{Ca}$ - mineralization in sulfuric acid and oxygenated water, determination by flame photometry, photometer PFP7 (Jenway, UK); $\mathrm{Mg}-$ mineralization in sulfuric acid and oxygenated water, determination by atomic absorption spectrometry, spectrometer Perkin-Elmer (USA); $\mathrm{Cu}, \mathrm{Zn}, \mathrm{Mn}$ and $\mathrm{Fe}-$ mineralization in perchloric and nitric acid (1:4), determination by atomic absorption spectrometry, spectrometer Avanta (GBC Scientific Equipment, Australia); $\mathrm{B}$ - oven mineralization with $\mathrm{Ca}(\mathrm{OH})_{2}$, determination by the spectrophotometric curcumin method, spectrophotometer Spekol (Carl Zeiss AG).

Phenolic content $(\mathrm{PhC})$. Rye flour $(0.5 \mathrm{~g})$ was extracted three times with $4 \mathrm{ml}$ of methanol/acetone/water 40:40:20, v/v/v. Extracts were centrifuged for $10 \mathrm{~min}$ at $6800 \times \mathrm{g}$, and supernatants were collected. Finally, the fractions from each step of extraction were combined and used for further analysis. The total phenolics were determined using Folin-Ciocalteau reagent (Singleton, Rossi, 1965). To $0.5 \mathrm{ml}$ of the sample, $0.5 \mathrm{ml} \mathrm{H}_{2} \mathrm{O}, 2 \mathrm{ml}$ Folin-Ciocalteau reagent $\left(1: 5 \mathrm{H}_{2} \mathrm{O}\right)$ were added, and after $3 \mathrm{~min}, 10 \mathrm{ml}$ of $10 \% \mathrm{Na}_{2} \mathrm{CO}_{3}$ and the contents were mixed and allowed to stand for $30 \mathrm{~min}$. Absorption at $725 \mathrm{~nm}$ was measured in a spectrophotometer UV-Vis (Shimadzu, Japan). The amount of total phenolics was calculated as a gallic acid equivalent (GAE) in $\mathrm{mg}$ per $\mathrm{g}$ of dry mass.

Total flavonoid content (FC) was determined according to the method described by Lamaison and Carnet (1990). One millilitre of extract was mixed with $1 \mathrm{~mL}$ of $2 \% \mathrm{AlCl}_{3} \times 6 \mathrm{H}_{2} \mathrm{O}$ solution and incubated at room temperature for $10 \mathrm{~min}$. Thereafter, absorbance at $430 \mathrm{~nm}$ was measured. Total flavonoid content was calculated as a quercetin equivalent (QE) in $\mathrm{mg}$ per $\mathrm{g}$ of dry weight (DW).

Reducing power (RP) was determined by the method of Oyaizu (1986). Analysed sample $(0.5 \mathrm{ml})$ was mixed with phosphate buffer $(0.5 \mathrm{ml}, 200 \mathrm{mM}, \mathrm{pH}$ 6.6) and potassium ferricyanide $\mathrm{K}_{3}\left[\mathrm{Fe}\left(\mathrm{CN}_{6}\right)\right](0.5 \mathrm{ml}$, $1 \%$ ). The mixture was incubated at $50{ }^{\circ} \mathrm{C}$ for $20 \mathrm{~min}$. Reactions were terminated by adding $0.5 \mathrm{ml} 10 \%$ TCA (trichloroacetic acid) and centrifuging for $10 \mathrm{~min}$ at 8000 $\times \mathrm{g}$. The upper layer of solution $(2.5 \mathrm{ml})$ was mixed with distilled water $(0.5 \mathrm{ml})$ and $0.1 \mathrm{ml}$ of $0.1 \% \mathrm{FeCl}_{3}$ and the absorbance was measured at $700 \mathrm{~nm}$. Increased absorbance of the reaction mixture indicated increase in reducing power. Reducing power was expressed as trolox equivalent (TE) in mg per $\mathrm{g}$ of $\mathrm{DW}$.

Metal chelating power (ChP) was determined by the method of Guo et al. (2001). The extract samples ( $1 \mathrm{ml}$ ) was added to $0.1 \mathrm{ml}$ of $2 \mathrm{mM} \mathrm{FeCl}$, solution and $0.2 \mathrm{ml} 5 \mathrm{mM}$ ferrozine and the mixture was shaken vigorously and left standing at room temperature for $10 \mathrm{~min}$. Then, absorbance of the solution was measured spectrophotometrically at $562 \mathrm{~nm}$. The percentage of inhibition of ferrozine- $\mathrm{Fe}^{2+}$ complex formation was calculated according to the formula:

$\%$ inhibition $=\left[1-\left(\mathrm{A}_{\mathrm{p}} / \mathrm{A}_{\mathrm{c}}\right)\right] \times 100$, where $\mathrm{A}_{\mathrm{c}}$ is absorbance of control, $A_{p}$ - absorbance of sample.

Chelating power was expressed as EDTA (ethylenediaminetetraacetic acid) equivalent in $\mathrm{mg}$ per $\mathrm{g}$ of DW.

Total starch content (TSC) was determined after dispersion of the starch granules in $2 \mathrm{M} \mathrm{KOH}(50 \mathrm{mg}$ sample, $6 \mathrm{ml} \mathrm{KOH}$ ) at room temperature ( $30 \mathrm{~min}$ at constant shaking) and hydrolysis of the solubilized starch with $80 \mu \mathrm{l}$ (1 mg ml-1) amyloglucosidase $\left(14 \mathrm{U} \mathrm{mg}^{-1}\right.$, EC 3.2.1.3) at $60^{\circ} \mathrm{C}$ for $45 \mathrm{~min}$ (Goni et al., 1997). Glucose content was determined by using the standard dinitrosalicylic acid (DNSA) method (Miller, 1959). Total starch content was calculated as glucose $\times 0.9$.

The free reducing sugar content (RSC) of the samples was determined in order to correct the obtained total starch values obtained.

Extraction of proteins. Total proteins were extracted according to procedure described by Hurkman and Tanaka (2007). For this method, $50 \mathrm{mg}$ of flour was suspended in $1 \mathrm{ml}$ of urea buffer: $2 \mathrm{M}$ urea, $10 \%$ glycerol, $65 \mathrm{mM}$ DTT (dithiothreitol) and $20 \mathrm{mM}$ Tris (2-amino-2-hydroxymethyl-1,3-propanediol, $\mathrm{pH}$ 8.0). 
The suspension was incubated at room temperature for 1 $\mathrm{h}$, and insoluble material was removed by centrifugation for $10 \mathrm{~min}$ at $16000 \times \mathrm{g}$. Protein content in samples was determined with the Bradford reagent (Sigma-Aldrich) according to the method described by Bradford (1976). Protein content was expressed as gluten equivalent in $\mathrm{mg}$ per g of dry weight.

Statistical analysis. The obtained results were statistically processed by the analysis of variance using statistical program ARStat (developed in the Faculty of Applied Mathematics and Information Technology of the University of Life Sciences, Lublin, Poland). The means were compared using the least significant differences based on the Tukey's test $(P \leq 0.05)$.

\section{Results and discussion}

Application of biochar changes soil properties depending on its type as well as biochar type and rate (Vaccari et al., 2011; Rogovska et al., 2014; Tammeorg et al., 2014). Therefore, interpretation of study results, seeking relationships and discussion with studies of other authors concerning the indirect effects of biochar on plants is a difficult task. In the present study, at the first assessment time (12 months after biochar application), the nitrogen $(\mathrm{N})$ content in winter rye grain from all biochar treatments was significantly higher than in the $\mathrm{BC}_{0}$ treatment (Table 1).

Moreover, the $\mathrm{N}$ content in grain harvested from the $\mathrm{BC}_{20}$ and $\mathrm{BC}_{30}$ plots was higher than in the other experimental treatments. Taking into account the fact that $\mathrm{N}$ content in plant material is affected by many factors, it is difficult to suggest the main reason why $\mathrm{N}$ content increased in the biochar amended treatments. Our previous study (Kraska et al., 2016) found that application of biochar positively affected the soil reaction and caused the significant increase of soil $\mathrm{pH}$. It is well known that soil $\mathrm{pH}$ plays an important role in the $\mathrm{N}$ nutrition of plants. Under conditions of higher $\mathrm{pH}$, the nitrification process is more rapid, and crops generally take up more nitrate. However, there are other factors, including soil moisture, temperature, texture, cation exchange capacity that can affect $\mathrm{N}$ content in grain of winter rye, but they were not studied in our experiment. In the second year of the study, a significantly higher grain $\mathrm{N}$ content, relative to the control $\left(\mathrm{BC}_{0}\right)$, was found in the treatment where 10 and $30 \mathrm{Mg}$ biochar had been applied. At the third assessment date, grain harvested from the control plots had lower $\mathrm{N}$ content than that from the biochar-amended treatments. Salim (2016) also found the N content in wheat grain to increase with increasing biochar amendment levels. Vaccari et al. (2011), in turn, found the N content in durum wheat grain not to be dependent on biochar application rate. According to Alburquerque et al. (2013) and Tammeorg et al. (2014), adding biochar to soil in the long term prevents leaching of nutrients beyond the agroecosystem and in consequence increases the amount of elements available to plants. In turn, the indirect effects of biochar involve its sorption capacity (retention of nutrients) and changes in soil physicochemical and biological properties, which leads to better nutrition of plants (Xu et al., 2013; Olmo et al., 2014).

Table 1. The content $\left(\mathrm{g} \mathrm{kg}^{-1}\right)$ of macroelements in winter rye grain harvested 12, 24 and 36 months after biochar addition to the soil

\begin{tabular}{|c|c|c|c|c|c|c|}
\hline $\begin{array}{l}\text { Assessment } \\
\text { date / year }\end{array}$ & Treatment & $\mathrm{N}$ & $\mathrm{P}$ & $\mathrm{K}$ & $\mathrm{Mg}$ & $\mathrm{Ca}$ \\
\hline \multirow{5}{*}{$\begin{array}{l}\text { After } 12 \\
\text { months }\end{array}$} & $\mathrm{BC}_{0}$ & $10.40 \mathrm{a}$ & $3.50 \mathrm{ab}$ & $4.70 \mathrm{a}$ & $0.800 \mathrm{a}$ & $0.293 \mathrm{a}$ \\
\hline & $\mathrm{BC}_{10}$ & $10.90 \mathrm{~b}$ & $3.53 \mathrm{a}$ & $4.70 \mathrm{a}$ & $0.814 \mathrm{ab}$ & $0.213 \mathrm{~b}$ \\
\hline & $\mathrm{BC}_{20}$ & $12.00 \mathrm{c}$ & $3.57 \mathrm{a}$ & $4.77 \mathrm{a}$ & $0.824 \mathrm{bc}$ & $0.227 \mathrm{~b}$ \\
\hline & $\mathrm{BC}_{30}$ & $11.80 \mathrm{c}$ & $3.40 \mathrm{~b}$ & $4.60 \mathrm{a}$ & $0.835 \mathrm{c}$ & $0.147 \mathrm{c}$ \\
\hline & $\mathrm{LSD}_{0.05}$ & 0.232 & 0.107 & 0.171 & 0.0176 & 0.0604 \\
\hline \multirow{5}{*}{$\begin{array}{l}\text { After } 24 \\
\text { months }\end{array}$} & $\mathrm{BC}_{0}$ & $11.83 \mathrm{a}$ & $3.35 \mathrm{a}$ & $3.16 \mathrm{a}$ & $1.387 \mathrm{a}$ & $0.310 \mathrm{a}$ \\
\hline & $\mathrm{BC}_{10}$ & $12.21 \mathrm{~b}$ & $3.26 \mathrm{a}$ & $7.98 \mathrm{~b}$ & $2.090 \mathrm{~b}$ & $0.510 \mathrm{~b}$ \\
\hline & $\mathrm{BC}_{20}$ & $11.95 \mathrm{a}$ & $3.39 \mathrm{a}$ & $5.86 \mathrm{c}$ & $0.639 \mathrm{c}$ & $0.525 \mathrm{~b}$ \\
\hline & $\mathrm{BC}_{30}$ & $13.14 \mathrm{c}$ & $3.32 \mathrm{a}$ & $5.27 \mathrm{~d}$ & $1.237 \mathrm{~d}$ & $0.403 \mathrm{c}$ \\
\hline & $\mathrm{LSD}_{0.05}$ & 0.228 & 0.132 & 0.328 & 0.0589 & 0.0375 \\
\hline \multirow{5}{*}{$\begin{array}{c}\text { After } 36 \\
\text { months }\end{array}$} & $\mathrm{BC}_{0}$ & $13.70 \mathrm{a}$ & $3.58 \mathrm{a}$ & $4.66 \mathrm{a}$ & $0.65 \mathrm{a}$ & $0.218 \mathrm{a}$ \\
\hline & $\mathrm{BC}_{10}$ & $16.80 \mathrm{~b}$ & $3.31 \mathrm{~b}$ & $4.28 \mathrm{~b}$ & $0.450 \mathrm{~b}$ & $0.202 \mathrm{~b}$ \\
\hline & $\mathrm{BC}_{20}$ & $17.20 \mathrm{c}$ & $3.53 \mathrm{a}$ & $3.61 \mathrm{c}$ & $0.383 \mathrm{c}$ & $0.178 \mathrm{c}$ \\
\hline & $\mathrm{BC}_{30}$ & $15.10 \mathrm{~d}$ & $3.55 \mathrm{a}$ & $3.22 \mathrm{~d}$ & $0.320 \mathrm{~d}$ & $0.302 \mathrm{~d}$ \\
\hline & $\mathrm{LSD}_{0.05}$ & 0.262 & 0.129 & 0.048 & 0.0155 & 0.0096 \\
\hline 2012 & \multirow{3}{*}{$\begin{array}{l}\text { Independent } \\
\text { of biochar } \\
\text { rates }\end{array}$} & $11.28 \mathrm{a}$ & $3.50 \mathrm{a}$ & $4.60 \mathrm{a}$ & $0.818 \mathrm{a}$ & $0.220 \mathrm{a}$ \\
\hline 2013 & & $12.28 \mathrm{~b}$ & $3.33 \mathrm{a}$ & $5.57 \mathrm{~b}$ & $1.338 \mathrm{~b}$ & $0.437 \mathrm{~b}$ \\
\hline \multirow[t]{2}{*}{2014} & & $15.70 \mathrm{c}$ & $3.49 \mathrm{a}$ & $3.94 \mathrm{c}$ & $0.442 \mathrm{c}$ & $0.225 \mathrm{a}$ \\
\hline & $\mathrm{LSD}_{0.05}$ & 0.094 & 0.174 & 0.082 & 0.0139 & 0.0160 \\
\hline
\end{tabular}

Note. $\mathrm{BC}_{0}$ - control treatment (without biochar), biochar rates: $\mathrm{BC}_{10}-10 \mathrm{Mg} \mathrm{ha}^{-1}, \mathrm{BC}_{20}-20 \mathrm{Mg} \mathrm{ha}^{-1}, \mathrm{BC}_{30}-30 \mathrm{Mg}^{-1}$; values marked with different letters differ significantly at $P \leq 0.05$. 
Atkinson et al. (2010) and Cao et al. (2017) have reported that in biochar-amended soils a change in soil $\mathrm{pH}$ occurs as well as soil microbial activity and the amount of available phosphorus increases. Likewise, Alburquerque et al. (2013) and $\mathrm{Xu}$ et al. (2013) found biochar to be a valuable source of plant available phosphorus. In the present study, at the first assessment time the $\mathrm{P}$ content in grain harvested from the $\mathrm{BC}_{30}$ treatment was significantly lower than in grain from the $\mathrm{BC}_{10}$ and $\mathrm{BC}_{20}$ treatments. In the second year after biochar application, the grain $\mathrm{P}$ content did not vary significantly. In the third year of the study, in turn, the lowest $\mathrm{P}$ content was found in grain harvested from the $\mathrm{BC}_{10}$ treatment. As part of the same experiment, Kraska et al. (2016) obtained a higher winter rye grain yield from the biochar-amended plots, which was probably attributable to greater nutrient uptake. Hence, the slightly lower $\mathrm{P}$ content determined in rye grain harvested from some biochar-amended plots was probably associated with the increase in grain yield and the nutrient dilution effect. Similarly, Olmo et al. (2014) have noted greater $\mathrm{P}$ uptake by wheat grown in biocharamended plots, with a higher yield and a slightly lower $\mathrm{P}$ content in grain, compared to the control treatment without biochar amendment.

The $\mathrm{K}$ content in rye grain did not vary significantly in the first year of the study. Such results could have been affected by the low level of rainfall in 2012 in the period from May to July (Fig.). Under water deficit conditions, plants take up and accumulate less nutrients. In the second year of the study, the lowest grain $\mathrm{K}$ content was determined in the control treatment without biochar. At this assessment time, the $\mathrm{K}$ content in grain from the biochar-amended treatments decreased with increasing biochar rate. In the third year of the study, a similar relationship was found in the grain harvested from the biochar-amended plots. However, the K content was highest in the grain from the control treatment. Similarly as in the case of $\mathrm{P}$, this was probably due to the fact that in the treatments with the highest BC application rate the rye produced a higher grain yield within the available pool of nutrients and hence the grain $\mathrm{K}$ content decreased (Kraska et al., 2016).

In the first year of the study, the highest amount of $\mathrm{Mg}$ was determined in grain harvested from the $\mathrm{BC}_{20}$ and $\mathrm{BC}_{30}$ treatments (Table 1). At the second assessment time, grain from the plots where $10 \mathrm{Mg}$ biochar had been applied was characterized by the highest $\mathrm{Mg}$ content, while the lowest one was found in the treatment $\mathrm{BC}_{20}$. In the third year of the study, the highest $\mathrm{Mg}$ content was determined in grain from the control treatments. Alburquerque et al. (2013) reported that wheat straw biochar incorporated into the soil reduced $\mathrm{Mg}$ uptake by plants. A certain confirmation of this finding was provided 36 months after biochar addition when the grain $\mathrm{Mg}$ content was found to decrease with increasing biochar application rate. Likewise, Olmo et al. (2014) determined the grain $\mathrm{Mg}$ content in wheat grown in biochar-amended plots at a level of $0.99 \pm 0.04 \mathrm{~g} \mathrm{~kg}^{-1}$, whereas in the control treatment without biochar amendment it was $1.08 \pm 0.04 \mathrm{~g} \mathrm{~kg}^{-1}$.
In the first year after biochar application, the highest amount of $\mathrm{Ca}$ was found in the grain from the control plots, whereas the lowest one in the treatment with the rate of $30 \mathrm{Mg}$ biochar (Table 1). In the second year of the study, in turn, its highest content was determined in the grain from the $\mathrm{BC}_{10}$ and $\mathrm{BC}_{20}$ treatments. In the third year after biochar application, the highest $\mathrm{Ca}$ content was found in grain harvested from the $\mathrm{BC}_{30}$ plots. Salim (2016) found the content of $\mathrm{P}, \mathrm{K}$ and $\mathrm{Mg}$ in wheat grain to increase under the influence of higher biochar rates. He observed a reverse relationship for $\mathrm{Ca}$ content. Alburquerque etal. (2013) also revealed decreased Ca uptake by wheat grown in wheat straw biocharamended plots. Olmo et al. (2014), on the other hand, determined a slightly higher Ca content $\left(5.52 \pm 0.12 \mathrm{~g} \mathrm{~kg}^{-}\right.$ $\left.{ }^{1}\right)$ in wheat grain in the control treatment without biochar amendment, compared to the treatment where biochar had been applied at a rate of $40 \mathrm{Mg}$ per hectare $(5.38 \pm$ $0.11 \mathrm{~g} \mathrm{~kg}^{-1}$ ).

Meteorological conditions during field experiment significantly influenced the content of macroelements in winter rye grain, except for $\mathrm{P}$. The highest amount of $\mathrm{N}$ was achieved in the third year of the study, while in 2013, which was wet and warm, the grain contained the highest $\mathrm{K}, \mathrm{Mg}$ and $\mathrm{Ca}$.

Twelve months after biochar addition, the lowest $\mathrm{Cu}$ content was determined in the grain obtained from the $\mathrm{BC}_{10}$ and $\mathrm{BC}_{20}$ plots. Similar trends were observed for the $\mathrm{Cu}$ content in the soil fertilized with biochar at rates of 10 and $20 \mathrm{Mg} \mathrm{ha}^{-1}$ (Kraska et al., 2016). At the second assessment time, the grain copper content was not significantly dependent on the biochar application rate, while three years after biochar application, in turn, the highest amount of copper was found in the grain from the $\mathrm{BC}_{30}$ treatment (Table 2).

In the first year of the study, the highest $\mathrm{Zn}$ content was determined in the grain from the $\mathrm{BC}_{30}$ plots, whereas in the second year in that from the $\mathrm{BC}_{10}$ and $\mathrm{BC}_{20}$ treatments. Thirty six months after biochar addition, grain harvested from the $\mathrm{BC}_{10}$ plot contained the largest amount of $\mathrm{Zn}$. In the study by Alburquerque et al. (2013), wheat straw biochar was found to promote $\mathrm{Zn}$ and $\mathrm{Cu}$ uptake by the crop plant. Olmo et al. (2014) found a lower $\mathrm{Zn}$ content in wheat grain harvested from biochar-amended plots $\left(24.4 \pm 1.1 \mathrm{mg} \mathrm{kg}^{-1}\right)$ than in the control treatment $\left(26.2 \pm 1.4 \mathrm{mg} \mathrm{kg}^{-1}\right)$. They noted a similar relationship with respect to $\mathrm{Cu}-3.5 \pm 0.2 \mathrm{mg} \mathrm{kg}^{-1}$ (control treatment) and $3.2 \pm 0.2 \mathrm{mg} \mathrm{kg}^{-1}$ (biochar treatment).

At the first assessment time, the grain Mn content in rye obtained from the biochar-amended treatments was higher than in the control plots, but grain from the $\mathrm{BC}_{30}$ treatment contained most manganese. Twenty four months after biochar addition to the soil, the highest $\mathrm{Mn}$ content was found in the grain from the control treatment. At the same time, it was demonstrated that the grain $\mathrm{Mn}$ content significantly increased with increasing biochar rate. The same relationship was found in the soil as affected by biochar amendment (Kraska et al., 2016). At the third assessment time, grain harvested from the $\mathrm{BC}_{10}$ 
Table 2. The content $\left(\mathrm{mg} \mathrm{kg}^{-1}\right)$ of microelements in winter rye grain harvested 12,24 and 36 months after biochar addition to the soil

\begin{tabular}{ccccccc}
\hline $\begin{array}{c}\text { Assessment } \\
\text { date / year }\end{array}$ & Treatment & $\mathrm{Cu}$ & $\mathrm{Zn}$ & $\mathrm{Mn}$ & $\mathrm{Fe}$ & $\mathrm{B}$ \\
\hline \multirow{3}{*}{ After 12 } & $\mathrm{BC}_{0}$ & $3.33 \mathrm{a}$ & $22.53 \mathrm{a}$ & $29.27 \mathrm{a}$ & $33.33 \mathrm{a}$ & $1.73 \mathrm{a}$ \\
months & $\mathrm{BC}_{10}$ & $2.53 \mathrm{~b}$ & $21.73 \mathrm{~b}$ & $34.40 \mathrm{~b}$ & $29.67 \mathrm{~b}$ & $1.37 \mathrm{~b}$ \\
& $\mathrm{BC}_{20}$ & $2.80 \mathrm{ab}$ & $21.60 \mathrm{~b}$ & $34.00 \mathrm{~b}$ & $28.33 \mathrm{~b}$ & $1.07 \mathrm{c}$ \\
& $\mathrm{BC}_{30}$ & $3.33 \mathrm{a}$ & $26.00 \mathrm{c}$ & $43.73 \mathrm{c}$ & $29.00 \mathrm{~b}$ & $1.37 \mathrm{~b}$ \\
\cline { 2 - 7 } After 24 & $\mathrm{LSD}_{0.05}$ & 0.641 & 0.427 & 0.770 & 3.460 & 0.151 \\
\hline \multirow{2}{*}{ months } & $\mathrm{BC}_{0}$ & $3.17 \mathrm{a}$ & $22.90 \mathrm{ac}$ & $53.33 \mathrm{a}$ & $20.46 \mathrm{a}$ & $4.07 \mathrm{a}$ \\
& $\mathrm{BC}_{10}$ & $4.20 \mathrm{a}$ & $26.33 \mathrm{~b}$ & $21.96 \mathrm{~b}$ & $40.38 \mathrm{~b}$ & $3.40 \mathrm{~b}$ \\
& $\mathrm{BC}_{20}$ & $3.41 \mathrm{a}$ & $24.00 \mathrm{a}$ & $38.76 \mathrm{c}$ & $27.40 \mathrm{c}$ & $4.60 \mathrm{c}$ \\
\cline { 2 - 7 } After 36 & $\mathrm{BC}_{30}$ & $3.21 \mathrm{a}$ & $21.76 \mathrm{c}$ & $47.16 \mathrm{~d}$ & $37.30 \mathrm{~d}$ & $1.18 \mathrm{~d}$ \\
\hline months & $\mathrm{LSD}_{0.05}$ & 1.049 & 1.388 & 1.725 & 2.338 & 0.321 \\
\hline & $\mathrm{BC}_{0}$ & $3.87 \mathrm{ab}$ & $30.20 \mathrm{a}$ & $33.00 \mathrm{a}$ & $37.40 \mathrm{a}$ & $3.78 \mathrm{a}$ \\
& $\mathrm{BC}_{10}$ & $3.47 \mathrm{a}$ & $32.01 \mathrm{~b}$ & $40.40 \mathrm{~b}$ & $39.10 \mathrm{~b}$ & $2.20 \mathrm{~b}$ \\
& $\mathrm{BC}_{20}$ & $4.01 \mathrm{~b}$ & $29.20 \mathrm{c}$ & $32.70 \mathrm{c}$ & $38.90 \mathrm{~b}$ & $2.11 \mathrm{~b}$ \\
\cline { 2 - 7 } 2013 & $\mathrm{BC}_{30}$ & $5.46 \mathrm{c}$ & $29.40 \mathrm{c}$ & $33.70 \mathrm{~d}$ & $32.70 \mathrm{c}$ & $1.39 \mathrm{c}$ \\
\hline \multirow{2}{*}{2012} & $\mathrm{LSD}_{0.05}$ & 0.471 & 0.329 & 0.223 & 0.212 & 3.178 \\
\hline
\end{tabular}

Explanations under Table 1

treatment was characterized by the highest Mn content, while the lowest one was found in that from the control plots without biochar. In the study by Alburquerque et al. (2013), Fe and Mn uptake by wheat decreased under the influence of biochar application. In turn, Atkinson et al. (2010), Major et al. (2010) and Olmo et al. (2014) found that the bioavailability and uptake of $\mathrm{P}, \mathrm{K}, \mathrm{Ca}, \mathrm{Zn}$ and $\mathrm{Cu}$ by plants in biochar-amended soils increased, whereas $\mathrm{N}$ leaching from the soil decreased. Tammeorg et al. (2014) and Gul et al. (2015) suggest that changes occurring in the soil under the influence of biochar amendment are dynamic, so it is difficult to conclude on the direct effects of biochar on plants.

In the first year of the study, in all biocharamended treatments a lower Fe content was found compared to the control treatment (Table 2). A similar relationship was revealed by Olmo et al. (2014) for wheat grain. At the second assessment time, a reverse situation was found - grain from the control plots contained least Fe. In turn, in the biochar-amended treatments grain from the $\mathrm{BC}_{10}$ plots was characterized by the highest $\mathrm{Fe}$ content. At the third assessment time, the highest Fe content was determined in rye grain from the $\mathrm{BC}_{10}$ plots, while the lowest one for the treatment where $30 \mathrm{Mg}$ of biochar had been applied. In the study by Salim (2016), an increased level of biochar amendment caused an increase in $\mathrm{Mn}$ and $\mathrm{Zn}$ content in wheat grain and at the same time a decrease in $\mathrm{Cu}$ content. In turn, $\mathrm{Fe}$ content varied depending on the growing season.

At the first and third assessment times, the B content in grain harvested from the control plots was significantly higher, compared to that harvested from the biocharamended plots (Table 2). This could have been attributable to the fact that biochar application resulted in an increase in soil $\mathrm{pH}$, which in consequence reduces the availability of $\mathrm{B}$ to plants (Kraska et al., 2016). Hu and Brown (1997) found a similar relationship; according to these authors, boron availability to plants decreases with increasing soil $\mathrm{pH}$ and therefore soil boron content increases.

In the first year of the experiment, the weather conditions were the least favourable for growing of winter rye (the lowest amount of rainfall). As a result, the lowest content of $\mathrm{Cu}, \mathrm{Zn}, \mathrm{Fe}$ and $\mathrm{B}$ in grain was found compared to the years 2013 and 2014. In turn, the highest amount of $\mathrm{Cu}, \mathrm{Zn}$ and $\mathrm{Fe}$ was achieved in 2014.

In the present study, biochar addition to the soil had a statistically proven effect on the biochemical parameters of rye grain (Table 3 ). A slight decrease in total protein content in rye grain was found in the $\mathrm{BC}_{10}$ and $\mathrm{BC}_{30}$ treatments compared to the control treatment, whereas in the $\mathrm{BC}_{20}$ treatment an increase was found, but the statistical verification did not confirm these differences to be significant. However, significant differences were shown between the $\mathrm{BC}_{20}$ and $\mathrm{BC}_{30}$ treatments. In the first year of their study, Tammeorg et al. (2014) obtained the highest protein content in spring wheat grain by applying a rate of $10 \mathrm{Mg}$ biochar per ha (a 3\% higher protein content compared to the control without biochar), whereas the lowest one in the treatment with a rate of $30 \mathrm{Mg} \mathrm{ha}^{-1}$ (a $2 \%$ lower content compared to $\mathrm{BC}_{0}$ ). In the second year of the study, on the other hand, these authors found higher grain protein content in 
Table 3. Comparison of nutraceutical potential of winter rye

\begin{tabular}{|c|c|c|c|c|c|c|c|c|}
\hline Factor & Treatment & TPC & TSC & $\mathrm{RSC}$ & $\mathrm{PhC}$ & $\mathrm{FC}$ & $\mathrm{ChP}$ & $\mathrm{RP}$ \\
\hline \multirow{5}{*}{ Biochar rate } & $\mathrm{BC}_{0}$ & $119.5 \mathrm{ab}$ & $524.2 \mathrm{a}$ & $8.86 \mathrm{a}$ & $3.96 \mathrm{a}$ & $0.06 \mathrm{ab}$ & $6.37 \mathrm{a}$ & $0.69 \mathrm{a}$ \\
\hline & $\mathrm{BC}_{10}$ & $118.5 \mathrm{ab}$ & $517.6 \mathrm{a}$ & $9.02 \mathrm{~b}$ & $6.8 \mathrm{~b}$ & $0.05 \mathrm{a}$ & $5.26 \mathrm{~b}$ & $0.71 \mathrm{a}$ \\
\hline & $\mathrm{BC}_{20}$ & $127.1 \mathrm{a}$ & $570.9 \mathrm{~b}$ & $5.76 \mathrm{c}$ & $3.12 \mathrm{c}$ & $0.06 \mathrm{ab}$ & $6.56 \mathrm{a}$ & $0.51 \mathrm{~b}$ \\
\hline & $\mathrm{BC}_{30}$ & $114.8 \mathrm{~b}$ & $487.7 \mathrm{a}$ & $6.12 \mathrm{~d}$ & $3.58 \mathrm{ac}$ & $0.07 \mathrm{~b}$ & $6.86 \mathrm{a}$ & $0.56 \mathrm{~b}$ \\
\hline & $\mathrm{LSD}_{0.05}$ & 9.42 & 46.23 & 0.045 & 0.616 & 0.018 & 0.80 & 0.07 \\
\hline \multirow{4}{*}{$\begin{array}{c}\text { Year } \\
\text { (independent of } \\
\text { biochar rates) }\end{array}$} & 2012 & $121.0 \mathrm{ab}$ & $537.8 \mathrm{a}$ & $7.30 \mathrm{a}$ & $4.39 \mathrm{a}$ & $0.06 \mathrm{ab}$ & $6.23 \mathrm{a}$ & $0.61 \mathrm{a}$ \\
\hline & 2013 & $114.7 \mathrm{a}$ & $519.9 \mathrm{a}$ & $7.60 \mathrm{a}$ & $4.15 \mathrm{~b}$ & $0.07 \mathrm{a}$ & $6.06 \mathrm{a}$ & $0.62 \mathrm{a}$ \\
\hline & 2014 & $124.3 \mathrm{~b}$ & $517.6 \mathrm{a}$ & $7.42 \mathrm{a}$ & $4.56 \mathrm{a}$ & $0.05 \mathrm{~b}$ & $6.50 \mathrm{a}$ & $0.63 \mathrm{a}$ \\
\hline & $\operatorname{LSD}_{0.05}$ & 6.78 & 34.79 & 0.336 & 0.230 & 0.012 & 0.51 & 0.05 \\
\hline
\end{tabular}

TPC - total protein content, $\mathrm{mg} \mathrm{g}^{-1} \mathrm{DW}$ (dry weight); TSC - total starch content, $\mathrm{mg} \mathrm{g}^{-1} \mathrm{DW}$; RSC - reducing sugar content, $\mathrm{mg} \mathrm{g}^{-1}$ DW; PhC - phenolic content, mg of GAE g-1 DW; FC - flavonoid content, $\mathrm{mg}$ of $\mathrm{QE} \mathrm{g}^{-1} \mathrm{DW}$; ChP - chelating power, mg of EDTA g ${ }^{-1} \mathrm{DW}$; RP - reducing power, $\mathrm{mg}$ of TE $\mathrm{g}^{-1} \mathrm{DW} ; \mathrm{BC}_{0}$ - control treatment (without biochar), biochar rates: $\mathrm{BC}_{10}-10 \mathrm{Mg}^{-1}$, $\mathrm{BC}_{20}-20 \mathrm{Mg} \mathrm{ha}^{-1}, \mathrm{BC}_{30}-30 \mathrm{Mg} \mathrm{ha}^{-1}$

the $\mathrm{BC}_{30}$ treatment relative to the control $\left(\mathrm{BC}_{0}\right)$ and the other biochar-amended treatments $\left(\mathrm{BC}_{5}, \mathrm{BC}_{10}\right.$ and $\left.\mathrm{BC}_{20}\right)$. But these differences were statistically insignificant.

In the treatment with the biochar rate of $20 \mathrm{Mg} \mathrm{ha}^{-1}$, a significantly higher total starch content was found, compared to the other experimental treatments, whereas the lowest total starch content value was determined for the grain from the plots where the biochar rate $30 \mathrm{Mg} \mathrm{ha}^{-1}$ had been applied. In the first year of the study, Tammeorg et al. (2014) showed the highest starch content in spring wheat grain from the $\mathrm{BC}_{30}$ treatment, whereas in the second year of the study the grain starch content was similar in all experimental treatments. In the study by Olmo et al. (2014), biochar addition had a beneficial influence on the biology of durum wheat growth and in consequence caused an increase in grain yield. Nevertheless, no significant influence of biochar on grain quality was demonstrated. The lack of significant changes in grain chemical composition with a simultaneous increase in crop yield can be considered to be a positive effect of biochar application for soil amendment.

Phenolic acids are the main antioxidants in cereal grains. They seem to have the greatest potential to be beneficial to our health as a result of free radical scavenging activity, inhibition of lipid peroxidation, and thus anticancer activity (Anson et al., 2011). The highest reducing sugar and phenolic contents were determined in rye grain from the plots where the lowest $\left(\mathrm{BC}_{10}\right)$ biochar rate had been applied. Moreover, in grain from the $\mathrm{BC}_{20}$ and $\mathrm{BC}_{30}$ treatments the content of reducing sugars and phenolics was lower than in the control treatment $\left(\mathrm{BC}_{0}\right)$.

Flavonoids play an essential role in the creation of the nutraceutical potential of cereals (Świeca et al., 2014). In the present study, the flavonoid content determined in grain from the plots where $10 \mathrm{Mg}$ of biochar had been applied was slightly lower than in the $\mathrm{BC}_{0}$ and $\mathrm{BC}_{20}$ treatments. On the other hand, a significantly higher value of flavonoid content was found in grain from the $\mathrm{BC}_{30}$ plots compared to $\mathrm{BC}_{10}$.
Soil amendment at different biochar rates did not have an unambiguous and clear effect on the antioxidant capacity parameters (chelating and reducing power) of rye grains. The lowest value of chelating power was determined in rye grain obtained from the $\mathrm{BC}_{10}$ treatment. In turn, the highest value of reducing power was found in the case of grain from the $\mathrm{BC}_{10}$ and $\mathrm{BC}_{0}$ treatments. Hung et al. (2011) reported that cereal grain, above all wheat grain, contains large amounts of polyphenols with well-documented antioxidant activity. Analysing the antioxidant activity and phenolic content of wheat grain, Falcioni et al. (2002), Okarter et al. (2010) and Hung et al. (2011) found proportional relationships between these parameters However, phenolic composition and antioxidant capacity of plant products are interaction mechanisms that occur in the plant in response to soil conditions and these mechanisms are still studied by researchers. Therefore, it is not always possible to explain the effect of changes in soil processes on crop yield quality (Różyło et al., 2015).

Weather conditions significantly affected the grain quality parameters. In the year 2013, winter rye grain was characterized by the highest flavonoid content, whereas the largest amount of total protein and phenolics was found in the year 2014 which was characterized by higher air temperature and rainfall compared to the longterm means.

\section{Conclusions}

1. In the experiment, significant differences in the content of the elements in grain of winter rye in the successive growing seasons were found. This, in turn, largely depends on the weather conditions and processes occurring in the soil. Moreover, plant growing conditions directly affect the possibility of uptake of nutrients from the soil solution and in consequence their accumulation in grain. The high content of elements in winter rye grain was obtained in the last year of the study in which the warm and wet weather positively affected the content 
of $\mathrm{N}, \mathrm{Cu}, \mathrm{Zn}$ and $\mathrm{Fe}$. In turn, the highest amounts of $\mathrm{K}$, $\mathrm{Mg}, \mathrm{Ca}, \mathrm{Mn}$ and $\mathrm{B}$ in winter rye grain were achieved in 2013. Unfavourable weather conditions probably were the primary cause of decrease of N, Ca, Cu, Zn, Fe and B in 2012 compared to 2013 and 2014.

2. The biochar application rates used in growing winter rye did not have an unambiguous and clear effect on the chemical composition of grain and its quality. It was only in the case of $\mathrm{N}$ that its higher content was determined in grain harvested from the biochar-amended plots at all assessment times (except for $\mathrm{BC}_{20}$ treatment in the second year of the study). Additionally, 12 months after biochar incorporation to the soil increase of $\mathrm{Mg}$ (except for $\mathrm{BC}_{10}$ ) and $\mathrm{Mn}$ and decrease of $\mathrm{Ca}, \mathrm{Fe}$ and $\mathrm{B}$ was found compared to the treatment without biochar. In the second assessment date, in the biochar treatments the content of $\mathrm{K}, \mathrm{Ca}$ and $\mathrm{Fe}$ in grain was significantly higher, and the content of Mn was significantly lower than in the control treatment, whereas in the third year of the experiment biochar caused significant decrease of $\mathrm{K}, \mathrm{Mg}$ and $\mathrm{B}$.

Received 08052017 Accepted 03112017

\section{References}

1. Alburquerque J. A., Salazar P., Barrón V., Torrent J., Campillo M. C., Gallardo A., Villar R. 2013. Enhanced wheat yield by biochar addition under different mineral fertilization levels. Agronomy for Sustainable Development, 33 (3): 475-484.

https://doi.org/10.1007/s13593-012-0128-3

2. Anson N. M., Aura A. M., Selinheimo E., Mattila I., Poutanen K., van den Berg R., Haenen G. R. 2011. Bioprocessing of wheat bran in whole wheat bread increases the bioavailability of phenolic acids in men and exerts antiinflammatory effects ex vivo. The Journal of Nutrition, 141 (1): 137-143.

https://doi.org/10.3945/jn.110.127720

3. Atkinson C. J., Fitzgerald J. D., Hipps N. A. 2010. Potential mechanisms for achieving agricultural benefits from biochar application to temperate soils: a review. Plant and Soil, 337 (1-2): 1-18.

https://doi.org/10.1007/s11104-010-0464-5

4. Bradford M. M. 1976. A rapid and sensitive method for the quantitation of microgram quantities of protein utilizing the principle of protein-dye binding. Analytical Biochemistry, 72 (1-2): 248-254. https://doi.org/10.1016/0003-2697(76)90527-3

5. Cao Y., Ma Y., Guo D., Wang Q., Wang G. 2017. Chemical properties and microbial responses to biochar and compost amendments in the soil under continuous watermelon cropping. Plant, Soil and Environment, 63 (1): 1-7. https://doi.org/10.17221/141/2016-PSE

6. Falcioni G., Fedeli D., Tiano L., Calzuola I., Mancinelli L., Marsili V., Gianfranceschi G. 2002. Antioxidant activity of wheat sprouts extract in vitro: inhibition of DNA oxidative damage. Journal of Food Science, 67 (8): 2918-2922. https://doi.org/10.1111/j.1365-2621.2002.tb08838.x
7. Farrell M., MacDonald L. M., Butler G., Chirino-Valle I., Condron L. M. 2014. Biochar and fertiliser applications influence phosphorus fractionation and wheat yield. Biology and Fertility of Soils, 50 (1): 169-178. https://doi.org/10.1007/s00374-013-0845-z

8. Goni I., Garcia-Alonso A., Saura-Calixto F. 1997. A starch hydrolysis procedure to estimate glycemic index. Nutrition Research, 17: 427-437. https://doi.org/10.1016/S0271-5317(97)00010-9

9. Gul S., Whalen J. K., Thomas B. W., Sachdeva V., Deng H. Y. 2015. Physico-chemical properties and microbial responses in biochar-amended soils: mechanisms and future directions. Agriculture, Ecosystems and Environment, 206: 46-59. https://doi.org/10.1016/j.agee.2015.03.015

10. Guo J. T., Lee H. L., Chiang S. H., Lin H. I., Chang C. Y. 2001. Antioxidant properties of the extracts from different parts of broccoli in Taiwan. Journal of Food and Drug Analysis, 9 (2): 96-101.

11. Hu H., Brown P. H. 1997. Absorption of boron by plant roots. Plant and Soil, 193 (1-2): 49-58. https://doi.org/10.1023/A:1004255707413

12. Hung P. V., Hatcher D. W., Barker W. 2011. Phenolic acid composition of sprouted wheats by ultra-performance liquid chromatography (UPLC) and their antioxidant activities. Food Chemistry, 126: 1896-1901. https://doi.org/10.1016/j.foodchem.2010.12.015

13. Hurkman W. J., Tanaka C. K. 2007. Extraction of wheat endosperm proteins for proteome analysis. Chromatography, 15: $344-350$.

https://doi.org/10.1016/j.jchromb.2006.11.047

14. Kraska P., Oleszczuk P., Andruszczak S., KwiecińskaPoppe E., Różyło K., Pałys E., Gierasimiuk P., Michałojć Z. 2016. Effect of various biochar rates on winter rye yield and the concentration of available nutrients in the soil. Plant, Soil and Environment, 62 (11): 483-489.

https://doi.org/10.17221/94/2016-PSE

15. Kuśmierz M., Oleszczuk P., Kraska P., Pałys E., Andruszczak S. 2016. Persistence of polycyclic aromatic hydrocarbons (PAHs) in biochar-amended soil. Chemosphere, 146: 272-279.

https://doi.org/10.1016/j.chemosphere.2015.12.010

16. Lamaison J. L. C., Carnet A. 1990. Nutritional, antioxidant and anti-inflammatory properties of Cyclanthera pedata, an Andinean fruit and products derived from them. Pharmaceutica Acta Helvetiae, 65: 315-320 (in French).

17. Lehmann J., Rillig M. C., Thies J., Masiello C. A., Hockaday W. C., Crowley D. 2011. Biochar effects on soil biota - a review. Soil Biology and Biochemistry, 43: 1812-1836.

https://doi.org/10.1016/j.soilbio.2011.04.022

18. Major J., Rondon M., Molina D., Riha S. J., Lehmann J. 2010. Maize yield and nutrition during 4 years after biochar application to a Colombian savanna oxisol. Plant and Soil, 333 (1-2): 117-128. https://doi.org/10.1007/s11104-010-0327-0

19. Miller G. L. 1959. Use of dinitrosalicylic acid reagent for determination of reducing sugar. Analytical Chemistry, 31 (3): 426-428.

https://doi.org/10.1021/ac60147a030 
20. Okarter N., Liu C. S., Sorrels M., Liu R. H. 2010. Phytochemical content and antioxidant activity of six diverse varieties of whole wheat. Food Chemistry, 119: 249-257.

https://doi.org/10.1016/j.foodchem.2009.06.021

21. Oleszczuk P., Jośko I., Futa B., Pasieczna-Patkowska S., Pałys E., Kraska P. 2014. Effect of pesticides on microorganisms, enzymatic activity and plant in biocharamended soil. Geoderma, 214-215: 10-18.

https://doi.org/10.1016/j.geoderma.2013.10.010

22. Olmo M., Alburquerque J. A., Barrón V., Campillo M. C., Gallardo A., Fuentes M., Villar R. 2014. Wheat growth and yield responses to biochar addition under Mediterranean climate conditions. Biology and Fertility of Soils, 50 (8): 1177-1187. https://doi.org/10.1007/s00374-014-0959-y

23. Oyaizu M. 1986. Studies on products of browning reaction - antioxidative activities of products of browning reaction prepared from glucosamine. Japan Journal of Nutrition, 44: 307-315.

https://doi.org/10.5264/eiyogakuzashi.44.307

24. Pranagal J., Oleszczuk P., Tomaszewska-Krojańska D., Kraska P., Różyło K. 2017. Effect of biochar application on the physical properties of Haplic Podzol. Soil and Tillage Research, 174: 92-103. https://doi.org/10.1016/j.still.2017.06.007

25. Prendergast-Miller M. T., Duvall M., Sohi S. P. 2014. Biochar-root interactions are mediated by biochar nutrient content and impacts on soil nutrient availability. European Journal of Soil Science, 65 (1): 173-185.

https://doi.org/10.1111/ejss.12079

26. Rogovska N., Laird D. A., Rathke S. J., Karlen D. L. 2014. Biochar impact on Midwestern Mollisols and maize nutrient availability. Geoderma, 230: 340-347. https://doi.org/10.1016/j.geoderma.2014.04.009

27. Różyło K., Gawlik-Dziki U., Świeca M., Różyło R., Pałys E. 2015. Winter wheat fertilized with biogas residue and mining waste - yielding and the quality of grain. Journal of the Science of Food and Agriculture, 96 (10): 3454-346. https://doi.org/10.1002/jsfa.7528

28. Salim B. B. M. 2016. Influence of biochar and seaweed extract applications on growth, yield and mineral composition of wheat (Triticum aestivum L.) under sandy soil conditions. Annals of Agricultural Science, 61 (2): 257-265. https://doi.org/10.1016/j.aoas.2016.06.001

29. Schimmelpfennig S., Kammann C., Moser G., Grünhage L., Müller C. 2015. Changes in macro- and micronutrient contents of grasses and forbs following Miscanthus $\times$ giganteus feedstock, hydrochar and biochar application to temperate grassland. Grass and Forage Science, 70: 582-599. https://doi.org/10.1111/gfs.12158

30. Schulz H., Dunst G., Glaser B. 2013. Positive effects of composted biochar on plant growth and soil fertility. Agronomy for Sustainable Development, 33 (4): 817-827. https://doi.org/10.1007/s13593-013-0150-0

31. Singleton V. L., Rossi J. A. 1965. Colorimetry of total phenolics witch phosphomolybdic-phosphotungstics acid reagents. American Journal of Enology and Viticulture, 16: 144-158.
32. Świeca M., Dziki D., Gawlik-Dziki U., Różyło R., Andruszczak S., Kraska P., Kowalczyk D., Pałys E., Baraniak B. 2014. Grinding and nutritional properties of six spelt (Triticum aestivum ssp. spelta L.) cultivars. Cereal Chemistry, 91 (3): 247-254. https://doi.org/10.1094/CCHEM-02-13-0019-R

33. Tammeorg P., Simojoki A., Mäkeläa P., Stoddarda F. L., Alakukku L., Helenius J. 2014. Short-term effects of biochar on soil properties and wheat yield formation with meat bone meal and inorganic fertiliser on a boreal loamy sand. Agriculture, Ecosystems and Environment 191: 108116. https://doi.org/10.1016/j.agee.2014.01.007

34. Vaccari F. P., Baronti S., Lugato E., Genesio L., Castaldi S., Fornasier F., Miglietta F. 2011. Biochar as a strategy to sequester carbon and increase yield in durum wheat. European Journal of Agronomy, 34: 231-238. https://doi.org/10.1016/j.eja.2011.01.006

35. Xu G., Wei L. L., Sun J. N., Shao H. B., Chang S. X. 2013. What is more important for enhancing nutrient bioavailability with biochar application into a sandy soil: direct or indirect mechanism? Ecological Engineering, 52: 119-124. https://doi.org/10.1016/j.ecoleng.2012.12.091

36. Zhang A., Liu Y., Pan G., Hussain Q., Li L., Zheng J., Zhang X. 2012. Effect of biochar amendment on maize yield and greenhouse gas emissions from a soil organic carbon poor calcareous loamy soil from Central China Plain. Plant and Soil, 351 (1-2): 263-275. https://doi.org/10.1007/s11104-011-0957-x 
ISSN 1392-3196 / e-ISSN 2335-8947

Zemdirbyste-Agriculture, vol. 105, No. 1 (2018), p. 11-20

DOI $10.13080 /$ z-a.2018.105.002

\title{
Elementụ kiekis žieminių rugiụ grūduose ir grūdụ kokybės parametrai, priklausomai nuo dirvožemio papildymo medžio anglimi
}

\author{
P. Kraska ${ }^{1}$, S. Andruszczak ${ }^{1}$, P. Oleszczuk ${ }^{2}$, M. Świeca ${ }^{1}$, E. Kwiecińska-Poppe ${ }^{1}$, \\ P. Gierasimiuk ${ }^{1}$, K. Różyło ${ }^{1}$, E. Pałys ${ }^{1}$ \\ ${ }^{1}$ Lenkijos gyvybès mokslų universitetas \\ ${ }^{2}$ Maria Curie-Skłodowska universitetas, Lenkija
}

\section{Santrauka}

Lauko eksperimentas 2012-2014 m. buvo atliktas paprastajame jauražemyje (Haplic Podzol, PZha). Tyrimo tikslas - ịvertinti medžio anglimi papildytame dirvožemyje augintų žieminių rugių grūdų cheminę sudètị. Nustatyti šie grūdų kokybės parametrai: N, P, K, Mg, Ca, Cu, Zn, Mn, Fe ir B kiekis, suminiai baltymų ir krakmolo kiekiai, redukuojančio cukraus, fenolinių junginių bei flavonoidų kiekiai ir chelatinè bei redukuojamoji geba. $2011 \mathrm{~m}$. prieš žieminių rugių sèją medžio anglis buvo panaudota vieną kartą trimis normomis: $10 \mathrm{Mg} \mathrm{ha}^{-1}$ (MA10), $20 \mathrm{Mg}$ $\mathrm{ha}^{-1}$ (MA20) ir $30 \mathrm{Mg} \mathrm{ha}^{-1}$ (MA30). Medžio anglis buvo pirolizuota iš kviečių šiaudų $350-650{ }^{\circ} \mathrm{C}$ temperatūroje. Rugių gūdų kokybės rodikliai buvo tirti kiekvienais metais po derliaus nuėmimo, t. y. po medžio anglies įterpimo i dirvožemị praejjus 12, 24 ir 36 mènesiams.

Visais vertinimo laikotarpiais rugių grūduose esantis N kiekis buvo didesnis iš medžio anglimi papildytų laukelių nei iš kontrolinio (MA0). Pirmaisiais tyrimo metais mažiausias P kiekis grūduose buvo nustatytas MA30 varianto $\left(3,40 \mathrm{~g} \mathrm{~kg}^{-1}\right)$, trečiaisiais - MA10 varianto $\left(3,31 \mathrm{~g} \mathrm{~kg}^{-1}\right)$ laukeliuose. Antrojo ir trečiojo vertinimo metu didinant medžio anglies normą $\mathrm{K}, \mathrm{Mg}$ ir Zn kiekis grūduose iš medžio anglimi papildytų variantų mažejo, o Mn kiekis didejo. MA30 varianto laukeliuose mažiausias Ca kiekis $\left(0,147 \mathrm{~g} \mathrm{~kg}^{-1}\right)$ grūduose buvo nustatytas pirmojo vertinimo metu, o po 36 ménesių jis buvo didžiausias $\left(0,302 \mathrm{~g} \mathrm{~kg}^{-1}\right)$. Pirmaisiais ir trečiaisiais tyrimo metais $\mathrm{Cu}$ kiekis buvo didesnis grūduose iš MA30 varianto laukelių nei iš MA10 (atitinkamai 31,6 ir 57,3\%). Antrojo ir trečiojo vertinimo metu, po medžio anglies panaudojimo praejjus 24 ir 36 mènesiams, Fe ir B kiekis grūduose, gautuose iš MA10 ir MA20 variantų laukelių, buvo didesnis nei MA30 varianto.

Antrojo ir trečiojo vertinimo metu, po medžio anglies panaudojimo praejjus 24 ir 36 mėnesiams, Fe ir B kiekis grūduose, gautuose iš MA10 ir MA20 variantų laukelių, buvo didesnis nei MA30 varianto. Grūduose, užaugintuose laukeliuose, tręštuose $20 \mathrm{Mg} \mathrm{ha}^{-1}$ medžio anglies, buvo nustatyti didesni bendri baltymų ir krakmolo kiekiai, palyginus su grūdais, augintais panaudojus $30 \mathrm{Mg} \mathrm{ha}^{-1}$ (atitinkamai 10,7 ir 17,1\%). Didžiausi redukuojančio cukraus $(9,02 \mathrm{mg}$ $\mathrm{g}^{-1}$ sausos masès $\left.(\mathrm{SM})\right)$ ir fenoliniu junginių $\left(6,8 \mathrm{mg}\right.$ galo rūgšties ekvivalento $\left.(\mathrm{GAE}) \mathrm{g}^{-1} \mathrm{SM}\right)$ kiekiai rugiu grūduose buvo nustatyti MA10 variante. Dirvožemio pagerinimas įvairiomis normomis medžio anglies neturejjo vienareikšmès ịtakos rugių grūdų antioksidacinès gebos parametrams (chelatų ir redukuojančiai gebai).

Reikšminiai žodžiai: elementų sudètis, grūdų kokybè, medžio anglis, Secale cereale. 